\title{
Alguma crítica: a dança do corpo poético em Um rio chamado tempo, uma casa chamada terra
}

\author{
Adriana Carolina Hipólito de Assis*
}

\section{Resumo}

Para além da compreensão da palavra e seus elos estritamente imanentes ou engajados, observa-se, atualmente, um novo linhavo da crítica literária ao eleger o corpo como matriz de expressão artística como suporte dos fenômenos artísticos nascidos do corpo. O presente ensaio procura evidenciar em Mia Couto em sua obra, Um rio chamado tempo, uma casa chamada terra (2003), uma África derivada de um tempo no qual a letra manifesta-se do corpo: performance coreografada das casasnarrativas africanas. Dança estilizada dos gestos e dos movimentos cíclicos de seus antepassados traduzidos todos, na voz de Mia Couto, como arabescos sheherazadianos da grande casa que a África habita.

\section{Palavras-chave}

Crítica literária. Corpo poético. Dança.

[...] Tudo ajuda a vida, Erixímaco, para que a vida nada conclua. Isto é concluir apenas a si mesma... Não é ela esse movimento misterioso que, pelo desvio de tudo o que acontece, transforma-me incessantemente em mim mesmo, e que me devolve bastante rápido a este Sócrates para eu o reencontre, e que imaginando necessariamente reconhecê-lo, eu exista! - Ela é uma mulher que dança, e que deixaria de ser mulher divinamente, se o salto que fez, pudesse obedecê-lo até as nuvens. Mas como não podemos ir ao infinito, nem no sonho nem na vigília, ela, de modo semelhante, reconverte-se sempre a si mesma; deixa de ser floco, pássaro, ideia; - de ser enfim tudo que a flauta quis que dela fosse feito, pois a mesma Terra que a mandou a convoca, e entrega-a toda palpitante à sua natureza de mulher $[\ldots]$.

VALERY, 2005, p. 15

\section{Da Introdução...}

Para além da compreensão da palavra e seus elos estritamente imanentes ou engajados, observa-se, atualmente, um novo linhavo da crítica literária ao eleger o corpo como matriz de expressão artística - acepção holística da poética que se estabelece no final do século XX e no começo do século XXI como produção de

\footnotetext{
* Mestre em Literatura e Crítica Literária pela PUCSP. E-mail: carolbas@terra.com.br
} 
sujeitos, talvez, esvaziados de investiduras críticas que não dão conta de um tempo vertiginoso como atual -, com um "retorno" ao elo primevo, ao suporte dos fenômenos artísticos nascidos do corpo.

E onde se situa a crítica diante da literatura africana? Na maior parte das vezes no engajamento poético, constituído como reflexo de sua submissão diante do poder constituído; como voz, que uma vez calada, deseja expressar seu grito de libertação artística. Mas há, ainda, outra África, de raiz dançante, e extremamente corpórea que festeja ou sente dor desde seus ancestrais. Uma África presente enquanto carne sulcada no espaço-tempo de seu povo. Nesta raiz dançante há uma coreografia em seus cenários que the confere identidade, além dos vários "Eus naturais" (MERLEAUPONTY, 1999), com seus elos hápticos, sinestésicos, táteis, olfativos e visuais que se manifestam na lógica de apropriação do seu ambiente corpóreo. O presente ensaio procura evidenciar em Mia Couto em sua obra, Um rio chamado tempo, uma casa chamada terra (2003), uma África derivada de um tempo no qual a letra manifesta-se do corpo: performance coreografada das casas-narrativas africanas. Dança estilizada dos gestos e dos movimentos cíclicos de seus antepassados traduzidos todos, na voz de Mia Couto, como arabescos sheherazadianos da grande casa que a África habita.

\section{Da crítica do engajamento à crítica do corpo poético...}

Não se trata aqui de estabelecermos o que comumente se discute nos bastidores acadêmicos quanto à crítica do branco para autores europeus versus a crítica do negro de caráter autóctone e oralizante e seus registros folcloristas devido, sobretudo, aos altos índices de analfabetismo presentes no continente africano; ou mesmo da permuta de códigos de correspondência comparativas entre as literaturas que dialogam com a África; ou, ainda, de diásporas que tematizam a saga dos espaços geográficos que desembocam, naturalmente, nas relações de dominação entre países, nos quais a literatura testemunha. Trata-se de buscarmos uma nova perspectiva crítica no que concerne à literatura Africana em relação ao corpo poético.

A crítica do engajamento se estabelece, geralmente, quando o objeto estético reflete um mundo caótico de dominação, de colonialismos, de exploração social e política no qual o ser humano presente neste mundo, tem seu espaço obliterado. Daí termos no bojo de sua discussão o retrato deste ambiente opressivo como afirma Maria Aparecida Santilli (1985) em Africanidade:

O longo período de domínio estrangeiro truncou o processo próprio ou espontâneo das nações africanas, compeliu-as à amnésia conjunta de suas tradições autóctones o que acabou por gerar, na resistência o reverso, isto é, a busca, o resgate de uma memória coletiva, a partir de dominadores comuns que levassem ao próprio pessoal ou nacional. (SANTILLI, 1985, p. 65).

Discussões como as de Santilli encontram ressonância em grande parte da crítica, na qual se observa paradigmas que se articulam num eixo extra-literário e/ou engajado e que se sobrepõe às questões relativas à forma poética. Existem pares de discussões críticas, assegura Benjamin Abdala Junior (1989), que oscilam entre 
literatura africana versus ideologia nas quais versam, geralmente, pela miscigenação cultural marcada pela dominação e pela apropriação; por comparativismo intertextuais que traçam elos com uma "ecologia cultural" (1989) entre África e Brasil, por exemplo; pelo primitivismo mítico/folclorista usado como alegoria nos embates ideológicos entre negros e brancos; e, por fim, pela oralidade e seus registros que apontam a cor local. Críticas que em sua maioria assinalam uma literatura que busca num período póscolonialismo a identidade ou a alteridade Africana ou Luso-africana que, por uma via ou outra, marcam um terreno puramente referencial.

Uma discussão um pouco enviesada quando se trata de Mia Couto, como aponta Celina Martins em $O$ entrelaçar das vozes mestiças - análise das poéticas da alteridade na ficção de Édouard Glissant e Mia Couto (2006), que afirma que sua escritura não deriva de uma primeira "safra" revolucionária de escritores preocupados com a militância de expressão poética para firmar a identidade de seu povo, mas, ao contrário, Mia Couto pertence a uma segunda geração que se propõe a uma escritura de identidade textual. O que, de certa forma, aponta para uma discussão mais imanente, uma vez que possibilita excursionarmos pela materialidade do signo poético. Daí encontrarmos críticas que intercambiam sua poética com a de autores brasileiros como Guimarães Rosa, conhecido pelo arrojo protéico de criações dos registros do sertão de Minas Gerais. Comparações que não perpassam pela transgressão da forma poética, mas como registro memorialístico da história. Há ainda comparativismo críticos que traçam alguns elos com a forma ao explicitarem os neologismos, as onomatopéias próprias dos registros oralizantes presentes tanto em Mia Couto quanto em Manuel de Barros e em Guimarães Rosa.

Mas o ponto fulcral está no projeto pedagógico de Mia Couto, embora Celina Martins o aponte como um escritor participante de uma segunda geração preocupada com questões estéticas, imanentes ao signo, observa-se o uso de uma espécie de xamanismo didático/alegórico com o intuito de reescrever uma África possível para branco ler:

[...] Em Mia Couto persiste a ideia de que a narração da história individual envolve e representa a experiência coletiva. Assim, a dimensão alegórica da sua ficção inscreve-se no contexto de uma literatura menor. (MARTINS, 2006, p. 275)

Diferente da leitura de Craveirinha que o vê como um tradutor da voz africana, como uma literatura de exportação. Algo em comum - embora diametralmente diferente enquanto forma poética - com a literatura brasileira que esteve à busca do "jeitinho brasileiro de ser" propondo, na voz de Oswald de Andrade (1978), uma releitura da Carta de Pero Vaz de Caminha para afirmar uma literatura que das raízes da colonização é antropofágica: uma literatura de exportação. Essa discussão também é abordada pelas mineiras Maria Nazareth Soares Fonseca e Maria Zilda Ferreira Cury (2008) que observam a alegoria como procedimento de escuta das vozes africanas:

Uma estratégia de construção textual pertinente para falar da terra arruinada, das tradições dilaceradas e da impossibilidade de representação do espaço nacional enquanto totalidade. (CURY; FONSECA, 2008, p. 58). 
O que por outro lado possibilita leituras críticas, assinaladas pelas autoras acima citadas, como uma forma de trazer "à cena um africano que vende tais imagens, em proveito próprio [...] imagens da África que alegorizam os conflitos e as contradições da terra e dos africanos na sua inserção no mundo contemporâneo" (CURY; FONSECA, 2008, p. 59).

Mia Couto traça um projeto pedagógico empenhadíssimo em combater o "afropessimismo"1 utilizando-se de bens simbólicos que possibilitam a "exemplaridade" da tradição como uma forma de reafirmar a identidade de seu povo, mas uma identidade mediada pela "negociação dos sentidos" (apud CURY; FONSECA, 2008, p. 104) e pela negociação dos conflitos entre brancos e negros. Saímos de uma crítica eminentemente engajada, revolucionária, para uma crítica que se encaminha para a pedagogia. Seus "exemplas", transmutados de uma linha horaciana de cunho puramente moralizante ou alegórico/educacional, pretende, por um lado, relacionar sua poética a projetos do governo, sobretudo por ter como proposta, desde a época em que militava na Frente de Libertação de Moçambique, a necessidade "épica" de escrever uma sociedade nova. E, por outro, em constituir uma marca poética que se encaminha para questões formais, ao abrir espaço - talvez derivado sua de formação acadêmica: Mia Couto é biólogo, professor e jornalista -, para uma escritura multiculturalista, assinalada pela coexistência das línguas orais de raiz e da língua portuguesa oficial, vozes inscritas em um ambiente de cosmovisão rural e urbana e de personagens marcadamente corpóreos.

Alejo Carpentier (1969) em conformidade com a crítica do engajamento, mas já pretendendo uma crítica identitária, observa a problemática do romance latinoamericano no final da década de 60 como um gênero tardio, no sentido de exportação poética, para ele países como da "Ásia, da África, que, possuindo uma poesia milenar, apenas agora começam a ter novelística" (1969, p. 11). Para o ensaísta os romances só se tornam grandes quando engendram uma dinâmica própria. Daí termos uma literatura que se volta às raízes do folclore. Alejo afirma que a literatura da América precisava remontar-se no sentido sélfico na busca de fontes folclóricas. "O folclore é à base de toda arte", garante o ensaísta, pois tudo "o que vem do povo tem de ser devolvido ao povo" (1969, p. 35). Na realidade o que Alejo propõe está para além da tematização folclorista ou alegórica ao buscar influências poéticas advindas do folclore russo que, conscientes de seu corpo poético, sempre primaram por aspectos formais advindos da música regional, das sonoridades buriladas polifonicamente, da dança coreografada do folclore. Sua preocupação, enquanto projeto poético que se desenhava no início de 1970, era não transformar a busca das raízes folclóricas como uma desculpa para comodismo no terreno de criação formal, era imperioso que se aliasse tanto um acento local, quanto universal na construção da literatura de seu tempo.

\footnotetext{
${ }^{1}$ Discurso de Mia Couto a propósito dos 30 anos de independência de Moçambique. Disponível em http://www.swissinfo.ch/por/Capa/Archive/Dircurso_de_Mia_Couto.html?cid=4581078. Acesso em: 23 jan. 2011.
} 
O folclorismo apontado por Alejo, como técnica de estilização, entra em consonância com o projeto pedagógico de Mia Couto que apresenta ecos do folclore africano na busca de um caminho local. Ainda na esteira de Alejo Carpentier, a crítica de Minas Gerais feita por Fonseca e Cury situa outro linhavo com as poéticas latinoamericanas buscando um enfoque "maravilhoso" nas obras de Mia Couto, não tanto pela hesitação construída entre o real e o sobrenatural, à moda latina americana, mas enquanto "tensão, no nível do discurso, entre realidade e fantasia, própria das produções populares" (FONSECA; CURY, 2008, p. 122). Uma tensão que se configura "nas expressões gestuais e na relação mais íntima com o corpo: na dança, no andar, na fala habitualmente erotizada" (FONSECA; CURY, 2008, p. 123/4), como corpo que se metamorfoseia diante da apreensão do espaço africano, mas que retorna, mais uma vez, a construção do projeto pedagógico: Mia Couto deforma a realidade concreta com a intenção marcadamente ideológica e referencial de educar. O que de certa forma não inviabiliza o manejo do autor quanto ao corpo poético que se movimenta sempre em direção ao engajamento politicamente correto.

O contraponto, aparente, da crítica pedagógica é situado por um largo campo de estudos acerca da oralidade, marcado, sobretudo pela transgressão da herança da colonização na busca da alteridade como mestiçagem cultural, perspectiva constituída através dos reescritos da oralidade, como bem aponta Celina Martins (2006). Mia Couto procura, por meio da oralidade e seus registros, não anular as línguas nativas incluindo-as à língua oficial portuguesa. A diferença, segundo Martins, estaria na forma como o autor o faz, estabelecendo para tanto, uma lógica rizomática de variantes orais em mise en abyme. É o que se verifica na introdução feita por Mia Couto na obra $O$ entrelaçar das vozes mestiças de Martins (2006):

\begin{abstract}
Quando em 1996, encontrei Édouart Glissant, no Brasil, eu não imaginava que uma acadêmica madeirense nos iria ligar por via de rizomas de pensamentos, etéros laços de saber e ternura. O antilhano Glissant (tal como antes dele, filósofos, como Deleuze e Guatarri) já reflectiu sobre o conceito de rizoma como forma de mestiçagem literária, defendendo a escrita como uma travessia, uma rede de insuspeitas cumplicidades. Apenas o rizoma fornece uma identidade aberta, disponível e apta a tornar-se propriedade de outros. [...] a escrita só vale enquanto tessitura, transculturação e viagem cujo destino não é outro senão a vontade de partir de novo. Pertenço a uma nação em estado de ficção, cuja identidade só é encontrada na procura da sua própria imagem. Essa ausência de moldura, esse retrato em movimento, esse ideioma em flagrante: tudo isso são materiais da minha inspiração. [...] Raiz e rizoma casam-se, por fim, para dizer que a história pode ser feliz se não termina nunca [...]. (MARTINS, 2006, p. 8. Grifos meus).
\end{abstract}

Decorrente dessa linha rizomática de construção poética da oralidade abriu-se espaço à crítica do corpo poético - definição que pontuarei mais a frente -, uma vez que estabelece pontes, mesmo que temáticas, com o corpo biológico. A via de introdução a essa crítica estaria em observar o objeto poético numa perspectiva inovadora, constituída, até o presente momento, pela ótica de Paul Zumthor. Foi à luz deste medievalista que o paulista Melquisedec Chaves Nascimento (2009) buscou respaldo à compreensão da literatura africana, recepcionada, até então, por registros 
ou pela contação de histórias com o intuito de se ritualizar a memória/identidade de seu povo.

A vertente zumthoriana possibilita a compreensão dos fenômenos relacionados à oralidade a partir do corpo, matriz de inserção neste mundo. A voz, como mídia primeira e extensão do corpo, possibilita a compreensão da oralidade na mediatização de uma mídia segunda: a escrita. Um corpo suporte de performances cunhadas por cada interprete no tempo e no espaço. Cada gesto oralizado extende-se do investimento corporal, no qual a sensorialidade emerge em cada performance narrativa. Essencialmente a crítica de Nascimento (2009) aponta para o gesto performático da oralidade, da voz presente na obra de Mia Couto.

O gesto performático em suas obras se dá não como participante concreto do ato narrativo, mas como ouvinte in loco das contações de histórias das quais ele se alimentou na construção de seu acervo pessoal: contos, mitos e folclore africano. 0 engajamento auditivo do autor possibilita imprimir em sua poética as sensações corpóreas tatuadas em sua memória. Nascimento, além de balizar seu estudo à luz de Zumthor, utiliza, ainda, colocações como às da escritora brasileira Cecília Meireles que se posiciona, tal como Mia Couto, como alguém que "gosta de ouvir" (apud NASCIMENTO, 2009, p. 14) para escrever. Inferência feita com propriedade, uma vez que Zumthor abarca em cada performance o elo indissociável da audição, da recepção. Já a diferença entre aquele que ouve para aquele que faz a performance narrativa possibilita pensarmos na figura do intérprete.

Para Paul Zumthor não há passividade neste ato (ouvir e fazer a performance), uma vez que ambos são afetados, tocados pela narrativa. A diferença estaria, sobretudo, na movência (ZUMTHOR, 1993, p. 144 a 158) conceito atribuído pelo medievalista, mas não tão explanado pela crítica de Nascimento (2009), uma vez que esse conceito abrange o "nomadismo memorialístico da tradição oral constantemente alimentado, ao longo da linha do tempo, por intérpretes que combinam a voz e o corpo em performances" (ASSIS, 2007, p. 29). A movência requer criação contínua dos espaços intervocais, intertextuais, virtuais presentes a cada performance feita por seu intérprete. Logo, a escuta de Mia Couto está totalmente mediatizada por variantes orais ou escritas constituindo assim, uma escuta tardia.

Neste intercâmbio de corpos que se movem e trocam entre si o narrar se estabelece a configuração do interprete. O problema do interprete Mia Couto está na construção de uma moldura para o rosto da África, é o que afirma, mais uma vez, Celina Martins em uma entrevista concedida a estudiosa em 22 de abril de 2002, e publicada em revista eletrônica: $O$ Estorinhador Mia Couto: a poética da diversidade²:

C.M.- É arriscado falar de literatura moçambicana agora?

MIA COUTO - Retomando a resposta anterior, não creio que não haja uma coisa que se possa chamar de Moçambique, há um retrato sem moldura, mas esse retrato pode ser definido, há traços comuns que permitem estabelecer uma certa identidade. Seria difícil dizer que um escritor angolano não caberia no mesmo projecto literário. Trata-se de uma literatura que está sendo feita. (MARTINS, 2002. Grifos meus)

\footnotetext{
${ }^{2}$ Disponível em: http://revistabrasil.org/revista/artigos/celina3.html. Acesso em: 29 dez. 2010.
} 
É preciso meditar sobre afirmações contidas na entrevista acima citada: "não creio que não haja uma coisa que se possa chamar de Moçambique, há um retrato sem moldura, mas esse retrato pode ser definido, há traços comuns que permitem estabelecer uma certa identidade." para se conceber o quadro da África. Essa expressão de Mia Couto que, mais uma vez, aponta para o projeto pedagógico, qual seja ser interprete de um continente sem moldura. Acaso a África não tem identidades? Não havia poéticas orais muito antes do advento do mundo grafo colonialista (ou pós-colonialista) com um desenho fundado? Talvez Parmênides ${ }^{3}$ seja um início de resposta para se pensar a raiz da poética de Mia Couto. Não há uma "certa identidade", há somente identidades constituídas dentro de uma cultura mestiça.

Por outro lado, afirmações como essas demonstram também o grande problema da crítica atual: dicotomizar pares de opostos: identidade versus não identidade inclusos no eterno embate da relação dos dominantes versus dominados no que se refere à África e a América Latina. $O$ avanço da crítica, até mesmo para aqueles que iniciam com as teorias de Paul Zumthor, pode ser observado pelo olhar do ensaísta e tradutor Amálio Pinheiro (1994) que busca compreender a configuração do corpo poético da América Latina, em sua obra Aquém da Identidade e Oposição Formas na Cultura Mestiça, que a propósito das dicotomias explicitadas acima, possibilita enxergarmos a falácia das escolhas de uma crítica mecanicista, que insiste em não compreender a forma de uma cultura mestiça. Como constata Amálio Pinheiro:

\begin{abstract}
Num país onde as linguagens se embutiram lexical e sintaticamente umas as outras (isso que na pele está em processo visível) desconfio do uso do termo negritude, cuja ideologia parece querer fundar uma objetividade nascida da reafirmação de uma suposta subjetividade negra. Assim como o sabor desses termos de origem africana é o terem deixado de sê-lo para participar desse sistema mutável de trocas que é a língua brasileira, tornando-se deglutíveis para poder exercer o poder da sua presença insinuante e contígua, assim a presença do negro mais se afirma quando, profanante e profanado dentro da circulação construtiva das linguagens da cultura, hibridiza-se no branco, no amarelo, no índio, ajudando a forjar esse estado de trânsito de semelhanças, texturas, parecenças, reciprocidades. (PINHEIRO, 1994, p. 45).
\end{abstract}

Dicotomias ainda perceptíveis em críticas que persistem em estabelecer fronteiras acirradas entre códigos verbais e não verbais; contador e ouvinte, como se fossem corpos que não se afetam. Ainda mais em poéticas contemporâneas que estabelecem, por exemplo, elos audíveis-visuais-táteis em um só corpo. Para o ensaísta,

\footnotetext{
3 Segundo Marilena Chauí o nascimento da Filosofia compareceram "[...] os primeiros filósofos que se preocupavam com a origem, a transformação e o desaparecimento de todos os seres. Preocupavam-se com o devir. Vimos também que dois filósofos do período pré-socrático adotaram posições opostas a esse respeito: Heráclito de Éfeso, que afirmava que somente a mudança é real e a permanência é ilusória, e Parmênides de Eléia, que afirmava que somente a identidade e a permanência eram reais e a mudança, ilusória." (CHAUÍ, 2003, p. 104-105).
} 
toda poética que se preze começa por fazer-se sinestésica e cenestésica, por implicar os sentidos do corpo na leitura. Falo não só do corpo físico, mas desse corpo-escritura, ou escritura-corpo, que os negros ajudaram em muito a construir na América Latina, trazendo para o campo da palavra o enovelamento mestiço e barroquizante do ritmo do tambor, dos quadris, do andar, e trazendo para o âmbito do significado de cada termo o estremecimento do significante, esse traço suprasegmetar, entonacional, que machuca o dicionário e o renova semanticamente. (PINHEIRO, 1994, p. 43).

A crítica de Nascimento (2009) propõe a inclusão do corpo poético enquanto voz mediatizada por Mia Couto. Entretanto, falta ainda, para que essa moldura crítica zumthoriniana se constitua demonstrar o patrimônio de uma cultura mestiça tal qual Amálio Pinheiro o faz ao deslizar seu olhar crítico no poema Sóngoro Cosongo, de Nicolás Guillén cuja língua se dá mestiça em sua base: "(hispano-afro-taína?)" sei lá que língua é essa, toda misturada! Uma "festa gráfico-corpóreo-vocal" (PINHEIRO, 1994, p. 32):

\author{
Ay, negra, \\ Si tu supiera! \\ Anoche te bi pasá \\ Y no quise que me viera. \\ A é tú le hará como a mí, \\ Que cuando no tuve plata \\ Te corrite de bochata, \\ Sin acoddate de mí. \\ Sóngoro cosongo, \\ Songo be; \\ Sóngoro cosongo \\ De mamey; \\ Sóngoro, la negra \\ Baila bien; \\ Sóngoro de uno \\ Sóngoro de tre \\ Aé \\ Bengan a be; \\ Aé, \\ Bamo pa be; \\ Bengan, sóngoro cosongo, \\ Songoro cosongo \\ De mamey! \\ (Apud PINHEIRO, 1994: p. 33)
}

Toda a ginga dançante dessa negra insinuante se dá pela presença erotizada "do signo vocal assim como o som para a grafia" (1994, p. 34) inserida nessa tríade amorosa de "Sóngoro la negra//Baila bien//Sóngoro de uno//Sóngoro de tre". A concretização signica, afirma Pinheiro, à luz de Zumthor, se dá pelo corpo, da "ação do olho/boca/ouvido" (1994, p. 33), associados por contiguidades de percepções 
sensoriais. Não se trata de se traçar uma crítica estritamente imanente ou engajada, mas de dominância poética de uma cultura mestiça sulcada no corpo.

Parafraseando Amálio Pinheiro é preciso pensar em uma poética que esteja aquém da pedagogia enquanto procedimento artístico. O questionamento crítico que ora proponho se deve, principalmente, por Amálio Pinheiro destinar um capítulo de sua obra antes mencionada para questões relativas à pedagogia do riso, na formação de uma cultura mestiça. Na esteira das teorias bakhtinianas e de Serres Michel em Mestiçagem Cultural, a Marca da Instrução no Terceiro Milênio (Pinheiro, 1994), o ensaísta propõe o riso como elemento essencial para se destronar o discurso oficial, monológico, presente, na maior parte das vezes, nas culturas que passaram pela colonização:

\begin{abstract}
Importa aqui o riso que se constrói a partir da necessidade de habitar-se do que é estranho. A respeito disso, diz Michel Serres, justamente falando de mestiçagem cultural no terceiro milênio: "Creio firmemente que o aprendizado só se faz a partir do momento em que a pessoa é extraída de uma situação primeira - sou isto, eu estou aqui - e aprender a não ser mais isto e não estar mais aqui". o humor que provoca este riso alimenta-se da experiência de crise e de diálogo entre dois textos: o primeiro, que pertence ao horizonte médio de expectativa geral; o segundo, que decepciona tal expectativa em que o corpo e a mente trivialmente se apoltronavam. Agora se instaura o pensamento duplo, a convivência com a dúvida criativa, com o número dois, a possibilidade de relação tensa entre o familiar e o estranho, a noção científica de ação e reação - sem o que o mundo é um amontoado amorfo de certezas recebidas por herança. (PINHEIRO, 1994, p. 35-6. Grifo meu).
\end{abstract}

O riso põe em risco, afirma o autor, as verdades fechadas ou "apoltronadas" do discurso oficial. Uma forma divertida de marcar o terreno ideológico das relações estabilizadas; ou presentes nas relações dos pós-colonizados ou dos póscolonizadores. A mestiçagem se daria, tal como explicita M. Bakhtin (1993; 1993b), na relação dialógica, na carnavalização dos discursos e variedades, nos quais festejam o espetáculo do riso, da dança. Educar pelo riso propõe aprendermos a rir criticamente e não conciliatóriamente: riso amarelo disciplinado, que ri para não chorar; mas rir às gargalhadas para antropomorfatizar o alheio, além disso, o riso, afirma Octavio Paz em Conjunções e Disjunções (1979) possibilita expurgar catártica e fisiologicamente a tensão, geralmente contida no corpo. A gargalhada está para além do riso, pois possibilita pensar no princípio do prazer. A gargalhada é

um regresso a um estado anterior; voltamos ao mundo da infância, coletiva ou individual, ao mito, ao jogo. [...] É resposta filosófica, como a gargalhada é a resposta mítica. A seriedade é o atributo dos ascetas e dos libertinos. A gargalhada é uma descontração; o ascetismo, uma rigidez: endurece o corpo para preservar a alma. (PAZ, 1979, p. 15).

Uma receita para se pensar em uma poética pedagógica, uma vez que se inscreve de modo menos alegórico. Mas, a pergunta que não quer calar é: precisa de algum tipo de pedagogia para se pensar em dominante poética jakobsoniana? 


\section{Pequeno panorama definitório(?) sobre o corpo poético?}

É preciso definir o que é "corpo poético"? Toda axiologia marca um território e exclui outros, entretanto, é preciso pontuar sua geografia a fim de expor panoramicamente uma "definição" que já está acadêmica-crítica e artisticamente pululando nos bastidores. Parece-me que, nestes casos, ensaiar é preciso para que possamos ampliar a crítica sobre Mia Couto. Assim, traçarei um recorte plural para constituir um pequeno panorama da crítica do corpo poético iniciado no século XX com o advento do modernismo com um salto à poesia concreta e ao começo do século XXI, momento no qual o corpo, como afirma Lucia Santaella (2004, p. 17), "vaza" para infinitas possibilidades de compreensão (dos eus e suas subjetividades) artísticas.

Pretender falar do corpo é descortinar o homem e o seu espaço por intermináveis caminhos. Assim, este ensaio-caminho procura traçar uma sucinta "classificação" sobre o corpo poético. Na literatura essa discussão inicia com o conceito antropofágico definido pelo modernista brasileiro Oswald de Andrade, a propósito da devoração dos elementos da cultura alheia com os da cultura local, valendo-se da prática do canibalismo dos índios tupis, que imolavam o inimigo. Concepção essa muitíssimo utilizada pelos adeptos da cultura mestiça ao cunhar sua expressão para indicar identidade e oposição ao colonizador: "Tupi, or not tupi that is the question" (ANDRADE, 1978: p.13). Antropofagia realizada por releituras do mesmo pelo riso, como aponta Amálio Pinheiro.

Derivado deste sacro movimento modernista o corpo poético parecia ter estagnado e, ao mesmo tempo, ter sido estilhaçado com o advento da revolução industrial, do mass media nos meios de comunicação e do cinema. Interessa para esse pequeno panorama a presença da Poesia Concreta que anunciava, embora compondo traços de um corpo simétrico e geometrizado, um espaço de poéticas derivadas da expressão verbivocovisual cunhada de James Joyce, que abria espaço, nesta conjunção de elementos, a um corpo sensorial, epifânico. A partir deste momento manifestam-se diferentes possibilidades de se pensar poéticas do corpo e suas devidas extensões: a poesia visual, a poesia sonora, até chegarmos à poesia semiótica da qual Décio Pignatari faz parte também. Suas poesias são, em sua maioria, táteis, sonoras, visuais, orgânicas no sentido biológico e sensual da palavra.

Na obra Poesia pois é poesia, de Décio Pignatari (1977), o corpo poético se delineia com mais força. É o que podemos observar nos poemas: "homem e woman" no qual as palavras são corpos que "transam" com os sentidos da androginia dos afetos; ou do poema "O Organismo", que metamorfoseia sua forma ao sensorializá-lo eroticamente por meio de recortes fílmicos de um corpo que quer prazer. Assim, o organismo biologicamente chega ao orgasmo. Nele, o corpo poético ganha sensação corpórea, à medida que suprime o sentido conceitual da palavra para ser pura sensação de gozo, é o que se percebe na última tomada, na qual o sentido se esvai para que o corpo compareça em prazer com a presença de uma única vogal "o": 


\section{a8008m}

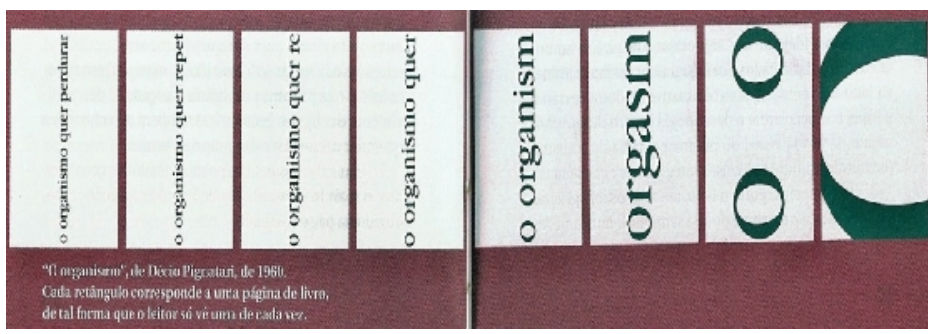

Figuras 1 e 2 -Homem e woman e O organismo.

Octavio Paz (1979), o grande precursor mexicano da crítica ensaística do corpo, verifica admirado as delícias corpóreas encontradas na literatura. Afirma o autor sobre a forma ou o método de se ler o corpo poético:

O mais assombroso é o método, a maneira de associar todos esses signos até tecer com eles séries de objetos simbólicos: o mundo convertido numa linguagem sensível. Dupla maravilha: falar com o corpo e converter a linguagem em corpo (PAZ, 1979, p. 18).

De lá para cá as linhas, ou o desenho do corpo poético, transforma-se em suporte dos mais variados meios, enquanto aparato midiático: do próprio corpo como suporte explorados artisticamente pelos adeptos do body art; da foto corpo poético; do vídeo corpo poético com precursores advindos da poesia concreta/visual e sonora; da moda do corpo poético, etc.

Possibilidades essas aplaudidas nos idos de 2005 com a exposição feita na Oca de São Paulo, pelo chileno Robert Edwards, com o projeto Corpos Pintados. Sinal que a cultura mestiça da America Latina concebe a arte como corpo com o intuito de se criar uma pedagogia não só para o riso, ou uma pedagogia de exemplário alegórico para se constituir um quadro, mas uma que estimule a percepção com a finalidade de reconstituirmos o respeito que o corpo merece ter no espaço deste mundo, afirma o chileno Edwards ${ }^{4}$.

Na sequência de imagens abaixo há uma recuperação deste homem tribal. Observe o diálogo que proponho na disposição entre o projeto Corpos Pintados, com o índio Selknam trajado para uma cerimônia de iniciação para comunicar-se com seu espaço sagrado. O corpo é a mensagem, afirma Flora Davis (1979). Um ser mensagem no mundo:

\footnotetext{
4 Ver mais em http://correiodobrasil.com.br/exposicao-corpos-pintados-e-prorrogada-em-saopaulo/90620/, acessado 10/01/2011.
} 

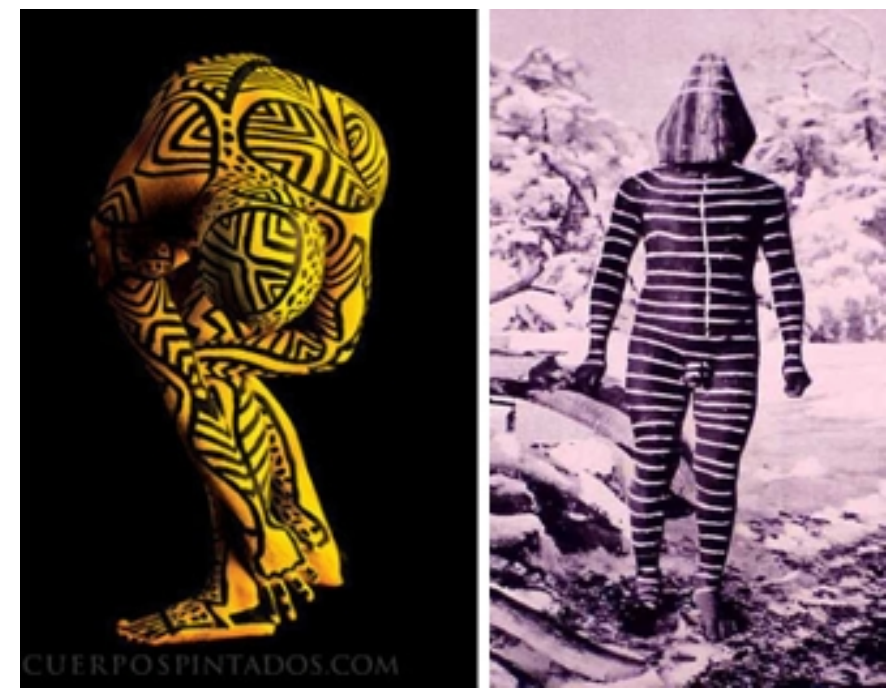

Figuras 3 e 4 - Corpos Pintados. ${ }^{5}$

Já na última imagem abaixo inserida, percebe-se uma proposta metalinguística que se desdobra em barroquismos. O corpo como matéria para consciência do próprio corpo: há que compreender as partes e o todo, consciência forjada pelas ferramentas que utilizamos em laço social:

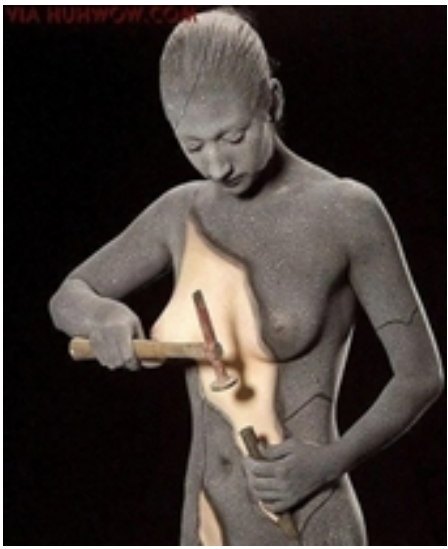

Figura 5 - O corpo como matéria para consciência do próprio corpo. ${ }^{6}$

Outra vertente interessantíssima para esse corpo poético é a poética da moda que, há muito, foi ressaltada por Roland Barthes como suporte estilístico. Um poema do vestir, que agora, ganha aparatos diametralmente diversificados com associações com a body art, por exemplo. Aspectos aparentemente distantes de concepções estritamente engajadas, imanentes ou pedagógicas que demonstram que, o que vestimos, pintamos ou tatuamos abriga ou veste a casa do corpo da nossa cultura, da nossa identidade.

\footnotetext{
${ }^{5}$ Disponível em: http://bacanissimo.files.wordpress.com/2008/02/bodypaiting.jpg

${ }^{6}$ Disponível em: bp1.blogger.com/.../s400/corpos_pintados01.jpg http://bacanissimo.files.wordpress.com/2008/02/bodypaiting.jpg
} 
Importa, ainda, alargamos um pouquinho mais a discussão desse corpo poético agregando-o a linhas de discussão que associam sua fronteira com o cenário urbano ou rural, com a extensão espacial e ambiental que indicam uma "dimensão espaço pessoal" (AMORIN; GREINER, 2003, p. 157) como proposta de estética do espaço que convivemos. As casas, afirma Jo Takahashi (2003), mimetizam a relação corpo pele, corpo carne (e por que não corpo vestimenta, corpo poema, corpo narrativa?!) para idealizar uma cidade, um espaço enovelado de corpos no mundo. Neste sentido temos corpos que vão - segundo Takahashi, na esteira de Richard Dawkins -,

\begin{abstract}
num processo de simbiose com o ambiente, e que vão sendo repassados como códigos genéticos. Essas ligações entre a biologia e a cultura abrem novas perspectivas sobre o futuro das cidades, discussão que já foge do atributo dos arquitetos, urbanistas e filósofos, e invade campos da biotecnologia e das ciências midiáticas. A mímesis poderia ser um instrumento de simbiose do corpo com a paisagem urbana e, adotada como memes, construiria uma cidade com códigos genéticos voltados para esta integração do corpo com a cidade. [...] a inserção do corpo se processa através da arte e dos mitos e faz de seu desenho urbano uma representação da genética própria. (AMORIN; GREINER, 2003, p. 155/6).
\end{abstract}

Todas essas possibilidades que apontamos acima se encontram, principalmente, nos embates críticos e teóricos da semiótica, mas que não estão sozinhos, pois há outras manifestações que buscam resposta para esse novo olhar. Parte dele advém da semiótica da cultura, contemplada no início deste ensaio com linhas advindas de Paul Zumthor e Amálio Pinheiro, no que concerne à compreensão de uma estética da cultura mestiça. Outras, ainda, com a proposta de Helena Katz - também semioticista - que busca na dança, na coreografia e no teatro elementos para se pensar o corpo poético. Daí em diante os limites para se pensar o corpo ganha espaço com linhas de discussão sobre o corpo prótese, o corpo robótico, o corpo ciberespaço (Santaella, 2004), etc. Isso sem contar com os estudos de cunho filosófico que, na maior parte das vezes, vale-se de conceitos que vão de Descartes, Antonio Damásio, Richard Dawkins, Deleuze e M. Ponty, todos interessados em compreender a geografia do corpo: corpo e mente; dentro e fora; alma e espírito conjuntamente a sinalização de seus endereços sensoriais - hápticos, táteis, visuais, etc - presentes em grande parte do corpo artístico.

O liame entre os códigos tornam-se holísticos, quando se trata do corpo poético. Outro paradigma estético que se manifesta para nos fazer refletir, com consciência, a natureza humana e seus espaços. Pensar em uma pedagogia poética, já que esta é uma marca de procedimento artístico de Mia Couto, faz-se necessário integrar o corpo à paisagem, como assinala Takahashi:

Ao artista cabe a função, já então esboçada, da criação de uma arte pública: transformar a visão e os conceitos na estrutura mais íntima do significado para poder dominar a outra estrutura maior, do mundo ambiental, das cidades. Trata-se de uma preocupação fundamentalmente coletiva, convocando a grande população a também agir no processo criativo. (AMORIN; GREINER, 2003, p. 159). 
Rizomas do corpo poético, à medida que reflete e refrata (BAKHTIN, 1993b) um corpo que respira arte e cultura. Observe a seguir como as narrativas sheherazadianas, por exemplo, estão em sintonia com o quadro e a moldura de seu povo, de modo a primar pela dominante poética.

\section{Corpo poético: dança coreografada de arabescos...}

A dança se configura no corpo, toda sua estrutura corpórea é posta em movimento, cada cultura apresenta maneiras de movimentar o corpo a partir do andar. O espaço do qual ele pertence possibilita inscrevê-lo de maneiras diferentes, marcado de acordo com seus grupos, tribos e fronteiras. A fisiologia do corpo possibilita um rebolar maior ou menor do que outras regiões. No Brasil é reconhecido o requebro de uma mulata que, quando caminha enche de graça, movimento transposto, sensualmente, pelos olhares dos passantes nas praias, nas ruas, até chegar às letras das músicas brasileiras. Como não olhar?! Fisiologia herdada do encontro de raças (índios, africanos, portugueses, etc).

É na dança-vestimenta-caligráfica-oralizante que Daisy Wajnberg (1997) nos brinda em sua obra Jardim de Arabescos - Uma Leitura das Mil e Uma Noites a simbiose mimética do corpo poético. Nela os arabescos, as tatuagens que vestem o corpo islâmico contornam os movimentos sinuosos e extremamente sensuais constituídos em seu território. Na sequência abaixo verificamos que da tatuagem feita nas mãos de uma mulher islâmica aos arabescos presentes na configuração da arquitetura das cidades, há uma linha de movimento rizomática, ondulante, labiríntica, embora simétrica em sua geometria que dão conta da movimentação de um corpo que esta física e espiritualmente junta. Tanto as tatuagens, quanto a caligrafia expressam essa dança. A letra está em consonância com a dança da voz, vestida, muitas vezes, em poemas filigranados, bismalas (figura 8) com o formato de uma fauna tão presente nas histórias islâmicas, que hoje a mídia cinematográfica expõe com filmes infantis, como o aclamado Azur e Asmar. ${ }^{7}$ Dança caligráfica presente nos azulejos, na música e nas orações islâmicas e, principalmente, na dança do ventre ou das narrativas sheherazadianas:

7 Disponível em: http://www.omelete.com.br/cinema/as-aventuras-de-azur-e-asmar/,. Acesso em 10 jan. 2011. 

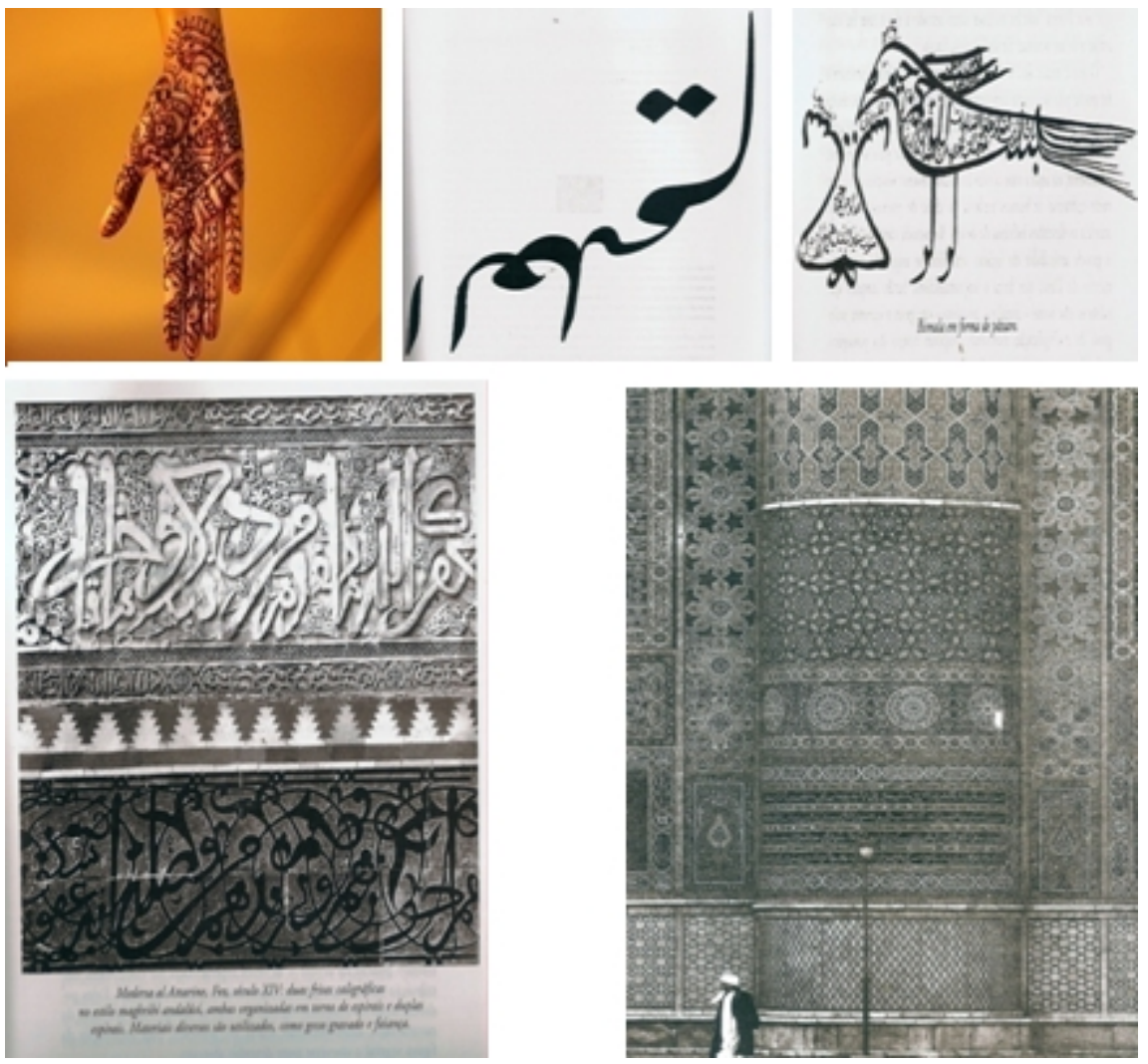

Figuras 6, 7, 8, 9 e 10 - Imagens. ${ }^{8}$

\section{O corpo poético à luz de DaisyWajnberg (1997)}

[...] vem a envelopar o objeto ao qual se aplica, vestindo-o numa espécie de pele, velando-o por véus sobrepostos. [...] A caligrafia não comporta apenas uma dimensão estética, ela diz respeito à verdade e alude fundamentalmente ao ser homem. (WAJNBERG, p. 141/3).

Corpo poético ismâlico que carrega em seu seio a exemplaridade nas manifestações de sua geografia, como afirma Daisy Wajnberg, à medida que a verdade da palavra está associada a Deus. O conteúdo das narrativas sheherazadianas é exemplo disso, assim como também de alegoria poética, embora apresente um trabalho formal extremamente apurado derivado, sobretudo da extensão do corpo sinuoso caligráfico que a narrativa veste. Outro aspecto que merece relevância é a dança do ventre. As mulheres quando dançam estabelecem esteticamente a ritualização dos mitos de fertilidade, pelos movimentos pélvicos e abdominais que revelam a origem do nascimento do mundo, concentrados todos no self umbigo. Joseph Campbell (1997) utiliza a expressão Axis Mundi como o "Centro do Mundo [...] símbolo da contínua criação: o mistério da manutenção do mundo através do contínuo

8 Primeira imagem disponível em: http://www.artenocorpo.com/sites/www. artenocorpo.com/files/Historia\%20da\%20Henna:\%20sua\%20origem\%201.jpg. Acesso em: 12 jan. 2011. As outras imagens foram retiradas da obra de Daisy Wajnberg em Jardim de Arabescos: uma leitura das Mil e Uma Noites (1997: p. 94, 129,136, 145). 
milagre de vivificação que brota no interior de todas as coisas" (1997, p. 46). O ventre é espaço ou a passagem do imaginário, o limiar do mundo mágico, é "uma esfera de renascimento simbolizada na imagem mundial do útero"(1997, p. 91).

Para que Sheherazade sobreviva à morte é preciso narrar. É na dança performática do narrar, muito próxima à dança do ventre, que os véus de sua tessitura vão sendo retirados. À medida que a moldura se modifica, modificam-se também os movimentos abdominais, sibilantes que advém do corpo umbigo, centro sélfico que guarda a memória gestada no corpo do Islã. Molduras que se desmontam circularmente em micro narrativas até se chegar ao umbigo-nascimento do filho do Sultão, momento no qual ele a perdoa. Um jogo barroquizante do narrar.

Um narrar pautado, obviamente, pela oralidade, mas uma oralidade movediça, tardia recepcionada por vários interpretes como afirma Daisy:

\begin{abstract}
Considere-se que para ambos documentos já citados, o livro das Noites seria baseado ou traduzido propriamente do Hasar Afsanah, livro este escrito em pehlevi. E Ibn na-Nadim assegura explicitamente ter tido em mãos o texto das Noites muitas vezes. Portanto, já não teríamos um registro puramente oral, mesmo que o Fihrist coloque na base deste gênero de narrativa os contos que circulam durante as noitadas na boca dos confabuladores nocturni. Assim, pode-se supor que as Noites seriam uma obra de compilação de dupla origem, para qual concorrem narrativas transmitidas oralmente pelos contadores de histórias e, por outro lado, obras escritas que posteriormente foram integradas à coleção. (WAJNBERG, 1997, p. 70).
\end{abstract}

Outra característica contida na dança do ventre está no caráter coreográfico, muito embora tenhamos na geografia memorialística do corpo islâmico, uma geometria perfeita equivalente a presença de Deus e aparentemente didática/modelar em seus gestos - no sentido de simetria do movimento -, verifica-se uma modalização ondular bastante livre na composição. O que configura a riqueza do aspecto formal das Noites.

São constantes as críticas, na contemporaneidade, que se valem de análises que associam os textos sheherazadianos a poética atual. Neste bojo crítico a dança em consonância com as poéticas do corpo estabelecem intersemioses com outros segmentos. Nelly Lacince e Terezinha Petrúcia Nóbrega expõem no artigo Corpo, dança e criação: conceitos em movimento (2010), o processo de criação e o engajamento do corpo na dança contemporânea. Importa destacar, deste trabalho, a correspondência, que verifico, entre esse corpo em movimento com a escritura. Assim como para Sheherazade há um desmontar de movimentos narrativos em dança, há neles muito de improvisação nos gestos narrativos, das performances que estão em constante risco, uma vez que ela pode ser morta pelo Sultão. Sheherazade era conhecedora não só da memória oralizante, mas também da estrutura dos gêneros, dos tipos de narrativas, mas, continuamente os mesmos, eram deslizados em moldes diferentes e encaixados. As autoras acima citadas observam, na entrevista feita com Mathilde Monnier dentre outros, esse deslocamento da rigidez da fórmula, do gênero, propondo ao dançarino o risco nos movimentos. Monnier afirma "a dança é conhecimento do corpo através do meio singular, o corpo, o movimento." (2010, p. 245). Suas coreografias baseadas em experiência étnicas marcam em sua trajetória, 
segundo Lacince e Nóbrega, a incorporação dos códigos corpóreos africanos, distintos em tudo do que, até então, o ocidente Ihe oferecia, justamente por vibrarem um gesto profundo: africano.

Interessa, neste ensaio, marcadamente barroquizante outro estudo: o da baiana Nadir Nóbrega Oliveira ${ }^{9}$ sobre etnocenologia, no qual verifica o cenário da dança afrobrasileira em Salvador, Bahia. Descreve um cenário que está para além do entretenimento de turistas enfatizando que sua prática é visceral, necessária no existir, como comer e dormir. As coreografias figuram sua inserção no espaço baiano. Seus

corpos deslizam espontaneamente, o requebro dos quadris em coordenação com os braços sem os tão conhecidos códigos gestuais de braços e pernas do balé, preocupando-se em preencher o espaço sem a rigidez da dança acadêmica. Dança esta que foge dos padrões homogêneos eurocêntricos impostos pelo mercado cultural. (OLIVEIRA, S/D, p. 63).

Afirma Oliveira que a dança afro-brasileira está prenhe da tradição, dos ancestrais negros que expressavam "todos os acontecimentos naturais da organização da sua comunidade: agradecer as colheitas, a fecundidade, o nascimento, a saúde, a vida e até a morte" (OLIVEIRA, S/D, p. 62). Característica de um dançar ou respirar a arte com movimentos policêntricos, uma vez que irradia por meio de vários centros enérgicos: pés, mãos, braços o movimento ctônico, que retira da terra sua energia, para que cada dança esteja associada ao ato de criar de todas as formas: letra, voz, desenhos tribais, meio ambiente etc.

\section{Mia Couto em sua casa: Um rio chamado tempo, uma casa chamada terra.}

"Para não dizer que não falei das flores... É claro, a crítica também quer arriscar."

Como não pensar em Gaston Bachelard (2000) quando uma casa se anuncia? E, como não pensar em obviedade no cruzamento dos signos: casa, terra e rio? Qual a sua moldura?

Um tempo teogónico, numinoso inspirado pelos deuses, eternamente circular em sua presença e no qual comparece o umbigo como origem corpórea de uma "casa concha" que guarda os segredos de seus ancestrais. Revelados a Marianinho, o herdeiro ou a extensão do corpo concha de seu avô Dito Mariano. Para constituir uma moldura é preciso fórmulas, daí o uso do folclore e dos mitos para emoldurar. Baseado nos mitos cosmogônicos Mia Couto anuncia a Matriz do Destino (CAMPBELL, 1997) de sua casa, situando em uma geografia, uma ilha denominada Luar-do-Chão. O centro umbilical de seu destino, de sua cicatriz memorialística:

\footnotetext{
${ }^{9}$ Disponível em: http://www.palmares.gov.br/_temp/sites/000/2/download/61\%20a\% 2063.pdf. Acesso em 20 dez. 2010
} 
A morte é como o umbigo: o quanto nela existe é a sua cicatriz, a lembrança de uma anterior existência. [...] ali onde se afunda o astro é o djambo, o umbigo celeste. A cicatriz tão longe de uma ferida tão dentro: a ausente permanência de quem morreu. (COUTO, 2003, p. 15. Grifos meus).

Luar-do-Chão advém do mito de origem, mito este estudado por Joseph Campbell pela inversão simbólica, na qual comumente vemos o homem como sol e a mulher como lua, afirma o mitólogo:

[...] Aqui, o homem original é a lua; a estrela matutina, sua primeira esposa; a estrela vespertina, a segunda. Da mesma forma como Väinämöinen emergiu do útero por seus próprios esforços, assim também esse homem-lua emerge das águas abissais. Ele e suas esposas serão os pais das criaturas da terra. (CAMPBELL, 1997, p. 295).

Inversão essa que coaduna com o sintoma do avô de Marianinho: catalepsia ou desambiguação constituída como metáfora de uma casa estática, no limiar da vida e da morte. Inversão que já anuncia o final da história, uma vez que se configura alegoricamente. No final, Dito Mariano, é enterrado às margens do rio Madzimi para simbolizar uma morte hierogâmica que engendra vida ao fertilizar a terra. Rio que encarna o feminino, uma vez que sua cor avermelhada, pelos sedimentos, simboliza o ciclo menstrual, além de encarnar a figura da mãe de Marianinho. Rio Ventre da Baleia que retira e devolve à origem de seus heróis aventureiros pela "passagem do limiar mágico para uma esfera de renascimento simbolizada na imagem mundial do útero, ou ventre da baleia" (CAMPBELL, 1997, p. 91). Da união entre o masculino e feminino se perpetua a tradição da terra pela morte/renascimento.

O ponto alto de Mia Couto (2005) está nesta moldura/mítica inicial, com a qual estabeleço pontes, ainda que diferentes, com as narrativas sheherazadianas, enquanto manejo da moldura da casa Luar-do-Chão com o umbigo memória do corpo. Tanto nas narrativas sheherazadianas quanto em Um rio chamado tempo, uma casa chamada terra há a presença de uma moldura inicial que, de modo distinto, deslizam a memória guardada no umbigo. Sheherazade dança o Islã para perpetuar a memória e viver, suas narrativas apresentam, na abertura, um conto-moldura que contém todas as outras histórias que são desenroladas de sua dança performática, de seu umbigo de Vênus. Já em Um rio chamado tempo, uma casa chamada terra há uma moldura dada pelo mito do Luar do Chão e da morte de Dito Mariano. Desta alegoria mítica Mia Couto constrói uma arquitetura narrativa tendo como centro o umbigo que se abre a cada espaço (quarto, quintal) da casa que a África habita. A manobra da alegoria mítica de Um rio chamado tempo, uma casa chamada terra se dá de modo circular, como dança semântica de movimento simbólico que vai do umbigo à África. A imagem que disponibilizo a seguir serve para ilustrar essa arquitetura emoldurada por Mia Couto, uma equivalência do umbigo como self da casa: 


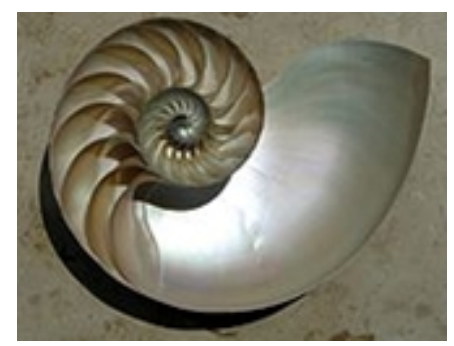

Figura 11 - Umbigo como self da casa. ${ }^{10}$

Os mitos, como é consenso, apresentam proporções sagradas em sua geometria. Suas narrativas servem para ritualizar/preservar a memória, portanto as partes têm que coadunar com o todo. Essas proporções divinas estão presentes em toda natureza, afirma Gaston Bachelard em A poética do Espaço (2000). A fenomenologia dá conta das essências factuais presentes no mundo que ali está. Os mitos servem para referencializar essa natureza corpórea que nos cerca no espaço e no tempo. Desta natureza fenomenológica Bachelard, procura compreender o homem a partir da sua relação com o espaço. A concha, examina o autor, é a morada dos moluscos, "construída como um eixo de uma espiral logarítmico" (2000, p. 117). Suas sucessivas hélices espirais dão conta de espaços geometrizados que escondem internamente a essência, e mostram o mistério de sua presença lenta e contínua na figura do molusco. Essa carapaça simbólica entre as metáforas alegóricas presentes na abertura do texto de Mia Couto como moldura, são fenomenologicamente condensadas no corpo umbigo de Dito Mariano:

\begin{abstract}
Na verdade, o ser que sai de sua concha sugere os devaneios do ser misto. Não é somente o ser "meio carne meio peixe". É o ser meio morto meio vivo e, nos grandes excessos, metade pedra metade homem. (BACHELARD, 2000, p. 120. Grifos meus).
\end{abstract}

Esse "ser misto", "meio vivo meio morto" possibilita criar devaneios que se encarnam à alegoria platônica que divide e reintegra o homem em partes, suspendendo-o no tempo eterno masculino, mas fluido por um rio mêstruo feminino. Devaneio sugerido por Bachelard, uma vez que trata de uma forma de habitação que se manifesta no imaginário que "atravessa os tempos":

Esses fatos da imaginação relacionam-se, aliás, com alegorias que atravessam os tempos. Jurgis Baltrusaitis lembra (...) que "até a época carolíngia, as sepulturas frequentemente contêm conchas em caracol - alegoria de um túmulo e que o homem vai ser despertado". Por sua vez, Charbonneaux-Lassay escreve (Le bestiaire Du Christ, p. 922): «Tomada em seu conjunto - carapaça e organismo sensível - a concha foi, para os antigos, um emblema do ser humano completo corpo e alma. A simbologia dos antigos fez da concha o emblema do nosso corpo, que encerra num invólucro exterior a alma que anima o ser inteiro, representado pelo organismo do molusco. (BACHELARD, 2000, p. 127. Grifos meus).

\footnotetext{
10 Imagem disponível em: http://pt.wikipedia.org/wiki/Espiral_logar\%C3\%ADtmica, Acesso em
} 20 jan. 2011. 
Habitação que guarda em segurança sempre uma parte do ser. Marianinho, por exemplo, entra em um quarto de bagunça do Luar-do-Chão: um lugar, um canto gaveta esquecido para manifestar seus desejos erotizados por mulher sem rosto, uma alegoria com a casa que é feminina:

\begin{abstract}
Vou pelo corredor, alma enroscada como se a casa fosse um ventre e eu retornasse à primeira interioridade. $\mathrm{O}$ molho de chaves que a Avó me dera retilinta em minha mão. Já me haviam dito: aquelas chaves não valiam de nada. Eram fechaduras antigas, há muito mudadas. [...] Excepto uma, no sótão, que abre a porta do quarto de arrumos. [...] De rompante, a porta se fecha. Sou engolido pelo escuro ao mesmo tempo que um corpo me aperta [...] A mulher sem rosto me mordisca no pescoço, engalinhando-me a pele. A voz dela é indecifrável, alteada pela ofegação: esbatida, desfocada, se insinua e me vai invadindo intimidades. Tudo acontece sem contorno, sem ruído, sem peso. Nunca o sexo me foi tão saboroso. (COUTO, 2005, p. 111-12).
\end{abstract}

Casa invisível enquanto órgão feminino de funcionamento da mística africana, cápsula dialética do dentro e do fora. O que esta dentro guarda a grandeza de um mundo em constante fertilização e perpetuação. Um mundo regido pelo feminino é um mundo sem fim, eterno como sua natureza corpórea, uterina. Os sentidos são espaciais, o corpo é lugar de apropriação sensória, háptica, tátil, olfativa. Pela sensação do corpo Marianinho ganha uma nova perspectiva em relação à NyumbaKaya. Afirma Merleau- Ponty (1999) é pela sensação que aprendemos os nossos Eus Naturais:

Pela sensação, eu aprendo à margem de minha vida pessoal e de meus atos próprios, uma vida de meus olhos, de minhas mãos, de meus ouvidos, que são tantos Eus naturais. (MERLEAU-PONTY, 1999, p. 291).

O corpo de Marianinho é iniciado pela casa mulher para que ele reaprenda a preservá-la, na medida em que aprende a sensorializar todas as partes da casa.

De outro modo, essa moldura guarda em sua concha casa segredos óbvios do narrar, pois Ihe retira a ambiguidade e a ambivalência tão característica da poética ao primar pela alegoria. Flavio René Kothe (1986) em A Alegoria explicita ao observar além do caráter didático presente nas narrativas alegóricas feitas todas, explicitamente, por aqueles que procuram fazer "doutrinação do leitor" (1986, p. 13) , nas figuras de retórica (prosopopéia/personificação e metáfora) um elo corpóreo muito interessante, relacionando-as ao platonismo: com um campo constituído por uma idealização, por um molde a ser seguido; com a contra partida corpórea que comparece como exemplário deste ideal de corpo/qualidades humanas.

Assim temos como alegoria maior a prosopopéia da casa como corpo feminino que circula por personagens constituídas como extensão do corpo de Dito Mariano: estáticas, catalépticas na movimentação do diafragma narrativo, isto é, não há profundidade em suas ações em grande parte. São personagens "tipos ${ }^{11 "}$ (SPINA,

\footnotetext{
${ }^{11}$ Segundo Segismundo Spina (1984) é comum nas obras vicentinas a presença das personagens "tipos", isto é, personagens tratadas como tipos sociais: o sapateiro, o frade, o fidalgo etc. Personagens que não têm profundidade em suas ações.
} 
1984), que apresentam ações modelares, planas: são só boas ou só ruins, além de serem designadas de acordo com os nomes que têm: "Abstinêncio", por exemplo, se configura como aquele que faz abstinência sexual, "Admirança", obviamente como aquela que, até mesmo, Marianinho deseja edipicamente. Alegorias que amortecem o discurso, tornando-o previsível enquanto Aura benjaminiana no campo das ideias. Marianinho, por exemplo, é considerado como um anjo por sua avó Dulcineusa, que, aliás, é bastante doce, por conter uma auréola/destino que o coloca na posição de herdeiro da Nyumba-Kaya e obviamente da África. Essa "auréola" surge como alegoria para equilibrar o sincretismo religioso de conotação católica à raiz africana. Ou ainda, aura aborígene-estereotipada do roubo da alma pela fotografia como explicação da catalepsia de Dito Mariano e obviamente de uma África sem alma, mas com corpo:

Por fim, alguém me dizia como falecera o Avô. Acontecera do seguinte modo: a família se reunira para posar para uma fotografia. Alinharam todos no quintal, o Avô era o único sentado, bem no meio de todos. [...] Dispararam-se as máquinas, deflagraram os flashes. Depois, todos risonhos, se recompuseram e se dispersaram. Todos, menos o velho mariano. Ele ficara, sentado, sorrindo. Chamaram-no. Nada. Ele permanecia como que congelado, o mesmo sorriso no rosto fixo. Quando o foram buscar notaram que não respirava. $O$ seu coração se suspendera em definitivo retrato. (COUTO, 2005, p. 57).

Quando as personagens "respiram" é para dar respaldo ao interdiscurso politicamente correto. Como na passagem na qual o tio de Marianinho recebe sangue de um homem branco:

[...] Enquanto Amílcar Mascarenha se ocupa se ocupa dos curativos, Ultímio vai falando:

- Esta noite nem dormi com essa história do sangue. É verdade, doutor, que me deram sangue de branco?

- Não sei que é isso.

- Não sabe o que é o quê?

- Sangue de branco.

Ultímio se arruma melhor na cama, soerguendo-se sobre as almofadas. Recusa a ajuda do médico, recupera o fôlego e, de novo, se dirige a Mascarenha:

- Eu gosto de si. Mas o meu ódio por si é muito mais antigo que eu.

- Está falar de mim ou de minha raça?

- Lamento, doutor, mas para mim, você é a sua raça.

- Não se preocupe, Ultímio: eu vou voltar para a capital. Você pode ficar descansado. (COUTO, 2005, p. 216-17. Grifos meus)

Respiração que, por um fio, comparece linearmente nos pequenos embates discursivos das relações entre capitalismo selvagem versus revolução ufanista e a tradição, além da clássica diáspora do dentro e do fora da ilha Luar-do-Chão. Ultímio, o tio de Marianinho, é expressão simbólica e hiperbólica deste quadro:

Meu Tio Ultímio, todos sabem, é gente grande na capital, despende negócios e vai politicando consoante as conveniências. A política é a arte de mentir tão mal que só pode ser desmentida é a arte de mentir tão mal que só pode ser desmentida por outros políticos. Ultímio sempre espalhou enganos e parece ter lucrado, acumulado alianças e influências [...] (COUTO, 2005, p. 28). 
É exatamente este manejo alegórico que é interessante em Mia Couto. Ao empregar a alegoria como matriz escritural, esvazia a profundidade poética no campo das ideias com o intuito de modalizar comportamentos, utilizando o corpo físico cataléptico como memória libidinal de suas trapaças amorosas (Dito Mariano teve muitas amantes), uma maneira de antropomorfatizar suas personagens como seres desejosos, um clichê para se falar de uma África "eroticamente selvagem". Memória corpórea: umbigo/corpo/voz; e etérea: idealização platônica de uma casa. Assim, a oralidade enquanto corpo/voz performático pretende, nesta cisão, dar uma moldura a um corpo sem alma. A oralidade movediça - tardia enquanto marca de uma oralidade primeira, pois se apresenta mediatizada virtualmente por um sincretismo religioso abrandado: uma forma de catequizar as superstições (feitiçaria versus carolismo) -, presente tanto na voz de Dulcineusa, quanto em outras personagens que refletem gestos que materializam semântica e sinédocamente o corpo/memória/oralidade de uma família viva; e, do espírito, corpo morto de Dito Mariano que envia cartas ao neto Marianinho com a intenção de perpetuar ou herdar a casa do Luar-do-Chão.

Não há alma porque não há corpo/dança, ritmo pulsante da vida. Paul Valery (2005) expõe as alegorias utilizadas dos diálogos socráticos presentes em sua obra Alma e a Dança e Outros Diálogos para evidenciar a dança como coreografa e coreografia principal da vida. As dançarinas ou qualquer personificação aludida a elas, em seus diálogos, manifestam-se como letra, como voz: "suas mãos falam, e seus pés parece que escrevem [...] Rhodopis é a outra (dançarina), que é tão doce, e tão hábil ao fazer carícias indefinidas com o olhar" (VALERY, 2005, p. 16/7). Todo o corpo escreve ao retirar do real matéria para se buscar a forma poética. É preciso pôr em risco suas personagens e enredo para que encarnem, para que criem carne de corpo poético. As personagens miacoutianas poderiam, como em uma dança tribal, seguindo seu ritmo se configurar por meio de movimentos policêntricos - como focos intensos em uma só voz tal como Dostoiévski o faz com as polifonias - se os discursos encarnassem os movimentos assimétricos da dança africana, mas, ao contrário, mantém uma linha simétrica/semântica exemplaria nos pequenos embates temáticos explicitados acima.

\section{Da conclusão...}

Todo esse arrazoado serve, não só para alargar as possibilidades críticas que podem ser inseridas às análises de Mia Couto, como também reiterar críticas já estabelecidas que o apontam com mestria escritural. De outro modo esta crítica pretende além de alargar perspectivas para que saíamos do mesmo, enfatizar a atitude alegórica de Mia Couto, não com o intuito de inseri-lo em uma crítica que o associa à literatura infantil (FONSECA; CURY, 2008) devido ao caráter alegórico de sua obra, como marca autoral, mas como um autor preocupado com a moldura de um povo que necessita de "moldar comportamentos" nos embates multiculturais presentes na África atual. Embora Mia Couto se ponha no papel sheherazadiano de composição memorialística de seu espaço no ato de narrar, sua performance enquanto interprete é tardia e linear, uma vez que se estabelece com um projeto pedagógico. É preciso arriscar formalmente, como afirma as coreógrafas citadas anteriormente, buscar na dança, na música que são viscerais ao povo africano, respaldo para poetar. Não pensar 
na moldura alegórica, mas no quadro já constituído do povo africano. Sheherazade, a guardiã da memória do Islã servia-se do exemplário em suas narrativas, mas o fazia arriscando formalmente em suas performances, uma vez que seu movimento corpóreo dizia tudo sobre a dança, a música, a cultura, a caligrafia, a arquitetura, a religião como corpo poético.

\section{Referências}

AMORIN, Claudia; GREINER, Christine (org.). Leituras do Corpo. São Paulo: Annablume, 2003.

ANDRADE, Oswald de. Obras Completas: Do Pau-Brasil à Antropofagia e às UtopiasIntrodução Benedito Nunes. $2^{\circ}$ Ed., Rio de Janeiro: Civilização Brasileira, 1970.

AQUINO, Dulce. A dança como tessitura do espaço. Disponível em: http://www.portalseer.ufba.br/index.php/ppgau/article/view/2643/1866, acessado em 10/12/2010.

ASSIS, Adriana Carolina Hipólito de. Corpo Poético. Disponível em: http://kplus.cosmo.com.br/materia.asp?co $=274 \& \mathrm{rv}=$ Literatura, acessado em 10/12/2010.

ASSIS, Adriana Carolina Hipólito de. O palimpsesto amoroso em Desmundo: contos de fadas. Lorena/SP: FATEA, 2007.

BACHELARD, Gaston. A poética do Espaço. São Paulo: Martins Fontes, 1993.

BAKHTIN, Mikhail. A Cultura Popular na Idade Média e no Renascimento - o contexto de François Rabelais. São Paulo: HUCITEC, 1993.

BAKHTIN, Mikhail. Questões de Literatura e de Estética - A Teoria do Romance. São Paulo: HUCITEC/Unesp, 1993b.

BARTHES, Roland. Mitologias. São Paulo: DIFEL, 1982.

BASEIO, Maria Auxiliadora Fontana. O sagrado em Mia Couto e Manuel de Barros. Disponível em: http://www.fflch.usp.br/dlcv/revistas/crioula/edicao/01/Artigos/08.pdf, acessado em 18/12/2010.

BASTOS, Maria Helena Franco de Araújo. A raiz da dança é o próprio corpo. Disponível em: http://www.portalabrace.org/.../dancacorpo/Maria\%20Helena\%20Bastos\%20-

$20 A \% 20$ raiz\%20da\%20dança\%20é\%200\%20próprio\%20corpo.pdf, acessado em $18 / 12 / 2010$.

BENJAMIN, Walter. A Obra de Arte na Época de suas Técnicas de Reprodução In: Benjamin, Walter et al. Textos Escolhidos, São Paulo: Abril Cultural, 1983.

BENJAMIN, Walter. O narrador In: Benjamin, Walter et al. Textos Escolhidos, São Paulo: Abril Cultural, 1983.

CAMPBELL, Joseph. O herói de mil faces. São Paulo: Cultrix/Pensamento, 1997.

CAMPOS, Augusto de. Poesia Antipoesia Antropofagia. São Paulo: Cortez e Morais, 1978. 
CARPENTIER, Alejo. Literatura e Consciência política na América Latina. São Paulo: Global Editora, 1969.

CHAGAS, Silvania Nubia. Nas fronteiras da memória: Guimarães Rosa e Mia Couto, olhares que se cruzam. Tese de Doutorado, USP/SP, 2006.

CHAUÍ, Marilena. Convite à Filosofia. São Paulo: Ática, 2003.

Corpos Pintados Disponível em: http://correiodobrasil.com.br/exposicao-corpospintados-e-prorrogada-em-sao-paulo/90620/, acessado 10/01/2011.

COUTO, Mia. Um rio chamado tempo, uma casa chamada terra. São Paulo: Cia da Letras, 2003.

DAVIS, Flora. A comunicação não-verbal, São Paulo: Summus, 1979.

FERREIRA, Sergio Buarque de Holanda, Novo Dicionário da Língua Portuguesa, $2^{\circ}$ Ed., Rio de Janeiro: Nova Fronteira, 1986.

FONSECA, Maria Nazareth Soares; FERREIRA, Maria Zilda. Mia Couto: espaços ficcionais. Belo Horizonte: Autêntica, 2008.

GIFFONI, Maria Amália Corrêa. Danças da Ásia, África e Oceânia. São Paulo: Nobel/Conselho Editorial de Cultura, 1974.

GUATTARI, Félix. Caosmose um novo paradigma estético. Rio de Janeiro:Ed. 34, 1992.

JAKOBSON, Roman. Linguística e Comunicação. São Paulo: Cultrix, 1995.

JUNIOR, Benjamin Abdala. Literatura História e Política - literaturas de língua portuguesa no século XX. São Paulo: Ática, 1989.

KOTHE, Flávio René. A Alegoria. São Paulo: Ática, 1986.

LACINCE, Nelly; NÓBREGA, Terezinha. Corpo dança e criação: conceitos em movimento. Disponível em:

http://seer.ufrgs.br/Movimento/article/download/10678/10018, acessado em18/12/2010.

MARTINS, Celina. O entrelaçar das vozes mestiças - análise das poéticas da alteridade na ficção de Édouard Glissant e Mia Couto, Portugal: Princípia, 2006. (e-book)

MARTINS, Celina. O Estorinhador Mia Couto. A Poética Da Diversidade Conversa com o escritor moçambicano no Funchal22 de Abril de 2002. Madeira/Portugal, Disponível em: http://revistabrasil.org/revista/artigos/celina3.html, acessado em 29/12/2010.

MENEZES, Philadelpho (org/introdução). Poesia Sonora - Poéticas Experimentais da voz no século XX. São Paulo: EDUC, 1992.

MENEZES, Philadelpho. Roteiro de Leitura: Poesia Concreta e Visual. São Paulo: Ática, 1998.

MERLEAU-PONTY, Maurice. Fenomenologia da percepção. São Paulo: Martins Fontes, 1999.

NASCIMENTO, Melquisedec Chaves do. Circunstancialidade da invenção em A Varanda do Frangipani, de mia Couto ente a letra e a voz. Mestrado em Lit. Crítica Literária, PUC/SP, 2009. 
OLIVEIRA, Nadir Nóbrega, O Corpo e Dança Negra no cenário artístico Soteropolitano, Disponível: www.palmares.gov.br/_temp/sites/000/2/download/61\%20a\%2063.pdf, Acesso em: 18 dez. 2010.

ORTIZ, Renato. A morte branca do feiticeiro negro. Petrópolis: Vozes, 1978.

PAZ, Octavio. Conjunções e Disjunções. São Paulo: Perspectiva, 1979.

PIGNATARI, Décio. Poesia pois é poesia. São Paulo: Duas Cidades, 1977.

PIGNATARI, Décio. Semiótica \& Literatura. São Paulo: Cultrix, 1987.

PINHEIRO, Amálio. Aquém da Identidade e da Oposição - formas na cultura mestiça. Piracicaba/SP: UNIMEP, 1994.

SANTAELLA, Lucia. Corpo e comunicação - sintoma da cultura. São Paulo: Paulus, 2004.

SANTILLI, Maria Aparecida. Africanidade. São Paulo: Ática, 1985

SPINA, Segismundo. Gil Vicente estabelecimento do texto. São Paulo: Brasiliense, 1984.

VALERY, Paul. A Alma e a Dança e outros diálogos. Rio de Janeiro: Imago, 2005.

WAJNBERG, Daisy. Jardim de Arabescos: uma leitura das Mil e Uma Noites. Rio de Janeiro: Imago, 1997.

ZUMTHOR, Paul. A Letra e a Voz - A "literatura" medieval. São Paulo: Cia das Letras, 1993.

ZUMTHOR, Paul. Introdução à Poesia Oral. São Paulo, HUCITEC, 1997.

\section{Title}

Some Criticism: The Poetic's Body Dance in Um rio chamado tempo, uma casa chamada terra.

\section{Abstract}

Beyond the understanding of the word and its strictly immanent or engaged links, one observes, nowadays, a new sewing of the literary criticism as it has elected the body as the matrix of artistic expression as a base for the artistic phenomena arising from the body. The present essay aims to evince in Mia Couto's Um rio chamado tempo, uma casa chamada terra (2003), an Africa that derives from a time when the letter is manifested on the body: coreographed performance of the African narrative-homes. A stylized dance of cyclical movements and gestures from the ancestors, all translated, in Mia Couto's voice, as Sheherazadian arabesques of the big house, which Africa inhabits.

\section{Keywords}

Literary criticism. Poetic body. Dance.

Recebido em 21.09.2011. Aprovado em 30.11.2011. 